\title{
CONSUMING NARRATIVES: THE POLITICS OF CANNIBALISM ON MT. LYKAION ${ }^{1}$
}

\author{
By Esther Eidinow
}

\begin{abstract}
Summary: This article examines a Classical reference to werewolves, a passing analogy made by Plato in the Republic, in his description of the development of a tyrant. In general, scholars of myth/ritual have largely downplayed or taken for granted the specific Platonic context; while philosophers have tended to overlook both Lykaian cannibalism, and the intricacies of political alliances in the early fourth century BC. This paper brings together three areas of investigation: philosophy, religion and political history, situating the myth/ritual complex of Lykaon/Mt. Lykaion within the framework of (1) Plato's Republic, where this myth/ritual is introduced analogically, and (2) fourth-century Peloponnesian politics, to which, it is argued, the Platonic werewolf analogy may be alluding, either in general or specific terms.
\end{abstract}

\section{THE WEREWOLF AS ANALOGY...}

\section{1. ... in Dialogic Context}

'What, then, is the starting-point of the transformation of a protector into a tyrant? Is it not obviously when the protector begins to do the same things as those in the story $(\dot{\varepsilon} \nu \tau \tilde{\omega} \mu u ́(\omega)$ that is told of the

1 I would like to thank the following for discussion relating to this paper: Jan Bremmer, Richard Gordon, Simon Hornblower, Madeleine Jost, Georgia Petridou, Jim Roy, and Jörg Rüpke. I am very grateful to Thomas Heine Nielsen for his support and to the anonymous reader for the journal. 
shrine of Lykaian Zeus in Arkadia?' 'What is that?' he said. 'The story goes that he who tastes of the one bit of human entrails minced up with those of other victims is inevitably transformed into a wolf. Have you not heard the account (

The central question of the Republic is expressed by Glaukon and Adeimantos - Sokrates' interlocutors - at the beginning of Book 2 (357a-b): is it better without exception to be just or unjust? The dialogue focuses on two key themes: the role of justice in individual happiness, and the nature of the ideal state and its institutions. Sokrates and his interlocutors discuss the different regimes: aristocracy, oligarchy, democracy and tyranny. The werewolf-myth analogy occurs at the end of a substantial discussion describing the development of democracy and oligarchy, and the way in which a democratic context gives rise to a tyrant. It plays on some of the imagery that Plato uses in this dialogue to examine and elaborate the structure and development of moral psychology. ${ }^{3}$ The nature and role of appetites and desires are crucial in this process: some of these are necessary and others unnecessary (558d); the latter do our souls harm, while the others do us good (558e-559c).

The appearance of the wolf comes as something of a shock, since the analogy used up to this point employs bees and their concern with the division of honey. In discussion of the democratic society, Sokrates divides the (political) population between i) drones who do nothing, some of whom have stings and others who are harmless; ${ }^{4}$ ii) those who have made money who provide the garden of the drones; and iii) the demos, that is the quiet cultivators of their own land, who possess very little property. In a democracy, it is the taste of honey that endangers a young man (559d-e) and leads him to develop an undisciplined democratic soul.

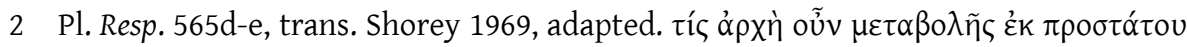

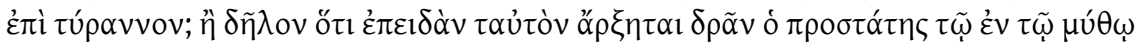

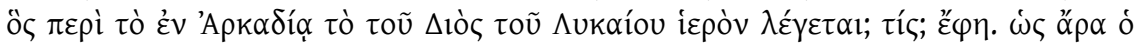

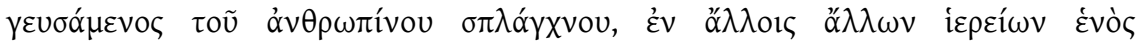

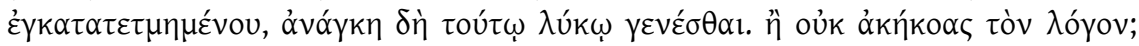
है $\gamma \omega \gamma \varepsilon$.

3 Brown 2011.

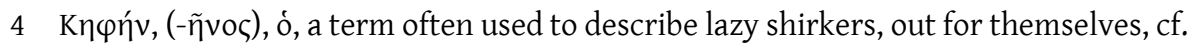
LSJ s.v. 
This temptation is provided by the drone (559c-d): 'who teems with such pleasures and appetites, and who is governed by his unnecessary desires, while the one who is ruled by his necessary appetites is the thrifty oligarchical man'. ${ }^{5}$ The tyrant emerges when those who have money defend themselves against the plundering drones, are accused of revolutionary plotting and, through no fault of their own, become oligarchs. The people, in response, put forward a protector. This is the character who runs the risk of becoming a tyrant-and about whom the werewolf analogy is used.

The werewolf analogy bridges themes found across the dialogue. Earlier in the conversation (375a-b), Sokrates has introduced the parallel of the guard-dog as a comparison for his city's guardians: keen in perception, swift in pursuit, strong, brave and full of spirit. ${ }^{6}$ The account of the werewolf recalls this canine imagery, but associates it with a very different set of behaviours, offering a vivid impression of the difference between the human figures that are the real focus of this discussion. But dog vs. wolf offers more than just a superficial contrast. As scholars have pointed out, this description of the dog may have taken contemporary audiences by surprise. The dog in pre-Classical literature was not viewed simply as a domesticated creature: Plato is one of the writers who "brings the dog in from the wild. ${ }^{7}$ It is perhaps precisely this ambiguous nature of the dog that creates such a powerful implicit comparison with the wolf. As Sokrates goes on to emphasise, the important characteristic of the dog, one that prevents it from using its qualities to attack rather than

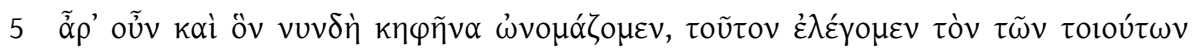

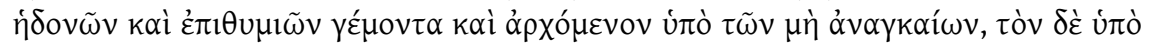

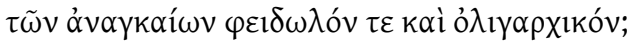

6 Bouvier 2015 examines this image and its implications for the role of Sokrates against Thrasymachos in the dialogue; see also Canto 1986. Note that Thrasymachos is compared to a wild beast (336b) in his interactions with Sokrates, and that he uses the analogy of the shepherd and flocks (343b), which is relevant here; see Brock 2013: esp. 45. Sinclair 1948: 61-62 argued that the dog analogy was intended to be seen as a parody of the argument used by those sophists 'who advised men to follow phusis not nomos'.

7 Mainoldi 1984: 196 draws attention to the novelty of Plato's dog-wolf opposition, and stresses how the dog in pre-Classical literature is situated between the wilderness and domesticity. 
defend its fellows, is that it has been trained, and so has been taught how to behave. The contrast between guard-dog and wolf encompasses not only their behaviour but also their potential to develop; it swiftly conveys everything that is wrong with both the actions and the nature of the tyrant.

The horror of the werewolf image is an important introduction to Plato's depiction of the tyrant, who is described elsewhere as being, fundamentally, a distressed individual, his soul dominated by a part that has no conception of what is best for the whole. ${ }^{8}$ As a microcosm of the tyrant's role in the city, this part runs the individual in order to satisfy its own particular aims. The image of a man corrupted by his consumption of human flesh, overtaken by an animal's ruthless and inhuman characteristics, works to reinforce what is, on closer examination, a rather feeble argument. (As Julia Annas has succinctly put it, 'Plato's tyrant would not last a week.') ${ }^{9}$ But in fact, the use of the image of the werewolf has its own problems if we take it, as is common, as evidence for the rites conducted by worshippers of Zeus on Mount Lykaion in Arkadia.

\section{2. ... as Evidence for Ritual}

As Richard Buxton observes: 'Plato speaks of a rite in which human innards are mixed with parts of other animals, and the person who tastes the human must turn into a wolf. ${ }^{10}$ This, in turn, is taken as describing the same ritual whose purported elements Pausanias reports (8.2.6): 'They say that ever since the time of Lykaon a man was always turned into a wolf at the sacrifice to Lykaian Zeus - but not for his whole life; because if he kept off human flesh when he was a wolf, he turned back into a man after nine years; if he tasted human flesh, he stayed a wild

8 This is lust, see $573 a-575 a$.

9 Annas 1991: 304.

10 Buxton 1987: 68. 
beast for ever. ${ }^{11}$ Some scholars have taken this to indicate that cannibalistic rituals were conducted on the mountain-an aspect to which we will return below. ${ }^{12}$

Whether this is the case or not, whatever happened seems to have involved temporary exclusion from the community: an individual underwent 'a rite of separation, left society and became temporarily a nonperson'. ${ }^{13}$ Modern scholarship makes a link with a further set of rituals described by Pliny the Elder and St. Augustine. ${ }^{14}$ In Pliny's version, a member of the family of Anthos is chosen by lot, leaves his clothes on an oak tree, swims across a pool, goes away into a deserted area and is turned into a wolf. If he does not consume human meat for nine years he is then permitted to come back again the same way, swimming across the pool, and reclaiming his clothes; in Augustine, the family of Anthos has become 'the Arkadians'. Both sources refer to a man whom they call

11 Trans. Buxton 1987: 69. Pausanias refuses to describe what occurs in the rituals on Mt. Lykaion (8.38.7); we should also bear in mind his scepticism when he recounts the story of Damarchos (see below); cf. Pirenne-Delforge 2008: 334-37.

12 As, for example, does Kunstler 1991: 193, who states that Pausanias is among the sources that 'clearly describe a werewolf society initiation'. Kunstler argues that werewolf imagery was more generally associated with tyrants in Greek literature, and particularly associates it with Lykourgos (drawing on Jeanmaire 1939), but does not attempt to set Plato's analogy in a historical context. See Brock 2013: 90 for examples of the literary image of the king as predator. Hughes 2013: 97 suggests that [Pl.] Minos 315b-c and Theophr. fr. 13.22-26 (in Porph. Abst. 2.27.2 Pötscher) are likely to be drawing on this passage in the Republic for their information about the practice of human sacrifice on Mt. Lykaion, and so should not be considered as providing further secure evidence. (However, later [104], he states that 'Plato and Theophrastus must be considered relatively reliable witnesses.') Bonnechere 1994: ch. I.4.1, \$131, n. 331 argues that such stories were circulating more generally in Athens. To date, the archaeological evidence has not offered evidence for human sacrifice, see Kourouniotis 1903; 1904a; 1904b; 1905a; 1905b; and 1909) and more recently the excavations of the Mt. Lykaion Excavation and Survey Project (http://lykaionexcavation.org/). The recent discovery of the tomb of a young man on the site immediately resurrected these stories of human sacrifice, but the archaeologists have denied that there is any such connection (see http://lykaionexcavation.org/site/research-highlights).

13 Buxton 1988: 71; Bremmer 2007: 71 finds this idea persuasive.

14 Buxton 1987: 69, citing Plin. HN 8.81 (citing Euanthes FGrH 320 F1) and Augustine De civ. D. 18.17 (citing Varro). 
Demainetos, an Olympic victor who had spent time as a wolf for nine years; it may indicate use of the same source. Pausanias reports an inscription recording the Olympic victory of one Damarchos, a boxer who had gone through the rite - although, Pausanias notes, this detail was not included in the epigram at Olympia. ${ }^{15}$

In these accounts, Walter Burkert sees reflected an original ritual initiation for the ephebes of the Arkadians. They gathered on the summit of Mount Lykaion and consumed the meat from the sacrifice that had been made during the ceremony, without knowing which was human and which animal. Those who ate the human meat were compelled to leave the community, only able to return if they did not eat it again for nine years. ${ }^{16}$ In the end, this initiation ceremony for all young men of a certain age came to be practised by only a single family: Burkert, developing these ideas, suggests that this was a result of a civilising effect created by the foundation of Megalopolis, when the sanctuary acquired a 'doublet' in the city. ${ }^{17}$ In turn, Madeleine Jost has rejected this, on the basis of Pausanias' observation that secret sacrifices were still being performed in his day: She has suggested instead, on the basis that the stories are related to similar themes, that the description of Anthos and his descendants refers to a different ritual performed elsewhere in Arkadia, perhaps near Tegea. ${ }^{18}$

15 Paus. 6.8.2. Most scholars treat Demainetos and Damarchos as the same person, but see Jost 1985: 259; and discussion by Hughes 2013: $232 \mathrm{n}$. 87 . The inscription has been dated to 'certainly before Alexander' (Hyde 1903: no. 74) and c. 400 (Moretti 1957: no. 359).

16 Others have observed that this was too long for a rite of passage: see Jost 1985: 267; Bonnechere 1994: ch. I.4.1, §139.

17 Burkert 1983: 89-90; the term 'doublet' is used by Jost in her analysis of the arrangement of new cults within the city of Megalopolis, which drew on existing Arkadian cults in the surrounding territory; see Jost 1985; 1992; 1994; 1996. Damarchos was, incidentally, a Parrhasian (that is, a member of the ethnos in whose territory this cult of Zeus Lykaios was established before the founding of Megalopolis), which may have some bearing on our approach to which group's young men were chosen to go through whatever experience was meant by 'becoming a wolf'.

18 See Jost 1985: 260; she points out that neither Pliny nor Augustine mention Mt. Lykaion in their accounts. She notes the focus on the hero Lykourgos in Tegea, and the fact that his name means 'celui qui fait les œuvres du loup'. 
This brings us back to Pausanias and his observations concerning the rites, or rather the stories told about them, in his day. Although the archaeological evidence has indicated that there may have been activities in the lower sanctuary in the period when Pausanias was writing, no cult activity has been traced in the upper sanctuary during that time. ${ }^{19}$ In light of this, we should pay attention to what is rarely mentioned about Pausanias' testimony: he is describing what people say about Mount Lykaion as an example of a story that has been elaborated to the point of being unbelievable. Indeed, he prefaces his description with this warning: 'All through the ages, many events that have occurred in the past, and even some that occur today, have been generally discredited because of the lies built up on a foundation of fact. ${ }^{20}$ Thus, it seems likely that these passages, along with brief mentions in other sources, suggest that stories about Mount Lykaion and the rituals there circulated in the Classical and Hellenistic periods, and were still circulating in Pausanias' time. But, as Pausanias emphasises, while this is not to say that the original tale does not contain a kernel of truth, we must be careful, because men are story-makers.

\section{3 ... as a Flawed Analogy}

Rather than focusing on the historical basis of the ritual, I want to consider the implications for its use as an analogy. Plato does not tell us very much, but it is clear that the ritual described here offered the individual in the role of the werewolf a chance of redemption. In contrast, the tyrant of Plato's description is given no such opportunity. Plato recounts the gradual, apparently unstoppable development of this man's crimes, led by and feeding his lustful soul-part. Not even when his own parents plead with him to stop his activities does the tyrant-in-training manage to refrain..$^{21}$ The parallel of the werewolf of the Mount Lykaion ritual, despite offering powerful imagery, is rhetorically flawed; it does not offer a useful analogy in this context.

19 Romano \& Voyatzis 2014; 2015.

20 Paus. 8.2.6.

21 Pl. Resp. 566d-580a, esp. 574b. 
That the tyrant cannot be redeemed is underlined by a number of tableaux in the final myth of Er at the end of the dialogue. One example is the description of the souls of the wicked, most of them tyrants, who, we are told, are forbidden release from their punishment, or are tortured and are to be hurled into Tartaros (615d-616a). There are also two further references that seem to reflect the werewolf imagery. The first is very brief, but perhaps ironic: it mentions the souls of the unjust entering the lives of wild animals (620d). More lengthy - and bringing a number of relevant themes together - is Plato's depiction of the soul who has drawn the first lot, who rushes to seize the life of tyranny, not realising that this will condemn him to consume his own children (619b-c). All three of these descriptions emphasise the idea that tyrants cannot be redeemed, even after they have died: The first pictures only punishment; the second and third imply that a course of life once chosen cannot be changed; the second can even be taken (with perhaps some implicit reference back to the werewolf) as suggesting that the life of an animal is better than that of a tyrant.

The purpose of this article is not to probe Plato's views on tyranny, nor is it to work out what may really have happened in a possible werewolf ritual. Rather, the question at issue here is why and how Plato uses the werewolf image from Arkadia if a reference to the ritual does not really work as an analogy for his argument - and, indeed, can be described as misleading. The explanation offered here starts by suggesting that Plato's analogy is not meant to be understood as describing the actualities of a ritual, but rather to direct his audience, first, to the myth that underpins that ritual, and its implications for approaches to leadership; and second, in that context, to what at the time were recent real-world events and a particular political leader. 


\section{THE MYTH(S) AND THEIR MEANINGS}

Lykaon was, as Buxton has dubbed him, 'a bringer of culture as a well as a criminal'; ${ }^{22}$ but we can go further than that. In our earliest source, attributable to Hesiod, Lykaon appears as a central figure in the genealogy, peopling and civilisation of Arkadia. His father is Pelasgos: The Pelasgians are much discussed across Greek myth, but usually play the role as 'the pre-Greek population in Greek consciousness'. ${ }^{23}$ In Arkadian myth, Pelasgos is the first inhabitant of Arkadia, and he is autochthonous, that is, he is from the earth, rooting this clan in its territory. ${ }^{24}$ Lykaon has sons that provide the names of key settlements across Arkadia: according to Apollodoros he produced fifty sons; Dionysios of Halikarnassos gives twenty-two sons ${ }^{25} \mathrm{He}$ is, in turn, grandfather of Arkas, perhaps a son of Zeus, who will invent agriculture, bread-making and weaving. ${ }^{26}$

Lykaon's downfall comes when he sacrifices a human baby, pouring its blood upon his altar to Zeus; he is immediately turned into a wolf. ${ }^{27}$ The accounts of this event vary: some implicitly, some more overtly, shift the blame for this crime elsewhere or simply explain it. In one fragment of the Catalogue, Lykaon serves the child in order to get his revenge on Zeus who has impregnated his daughter. ${ }^{28}$ Some versions put the blame

22 Buxton 1987: 73.

23 Fowler 2013: 2.84-96 and 87 for quotation (italics in original). Father of Lykaon, Hes. fr. $161 \mathrm{MW}$.

24 Hes. fr. $160 \mathrm{MW}$ and Asios fr. 8. Acknowledged also by Akousilaos fr. 25, who offers a competitive role for Pelasgos in the Argive myth stemma; see Fowler 2013 vol. ii: 88.

25 [Apollod.] 3.8.1; Dion. Hal. 1.13.1-2 (who appears to be drawing on Pherekydes). Some individual names are given in Hes. fr. 162 (Pallantos) and fr. 163 (Eumelos). The names are listed in Roscher, Lex and RE; see also Wilamowitz 1971: 152-56. Nielsen 2002: 235, n. 36 argues that this list must pre-date 368. Pausanias lists twenty-eight sons: see further Roy 1968 for what this shows about the situation after the foundation of Megalopolis.

26 Paus. 8.4.1. Arkas as son of Zeus and Kallisto, daughter of Lykaon (Hes. ap. [Eratosth.] Cat. (fr. 163 MW, with Fowler 2013: 2.104); also Eumelos fr. 7), but elsewhere, simply a nymph (Hes. ap. [Apollod.] 3.100).

27 Paus. 8.2.1-7.

28 As Fowler 2013: 2.105, this justification is removed if Kallisto is in fact a nymph (see n. 22). 
on Lykaon; ${ }^{29}$ others on his sons. In Apollodoros, Zeus is testing the impiety of these young men, and arrives disguised as a day-labourer. ${ }^{30}$ In other sources, the sons are testing the identity of their visitor - is he really a god? ${ }^{31}$ The identity of the person sacrificed varies too. Some keep it in the family: The Hesiodic fragments describe it as Arkas, Lykaon's grandson; ${ }^{32}$ later sources say it is Lykaon's son, Nyktimos. ${ }^{33}$ Apollodoros offers a local child; other sources simply leave it undescribed, even as just human flesh. ${ }^{34}$ Servius gives us a guest and the story becomes a warning fable not to violate the laws of hospitality; Ovid, a Molossian hostage. ${ }^{35}$

In modern times, some scholars have also seen here evidence to support the reality of a cannibalistic ritual. Jost observes that the story of the banquet in a number of accounts recalls, through the vocabulary used, a sacrifice. ${ }^{36}$ She notes 'on accorde plutôt confiance aux textes des Anciens et l'on voit dans le rite du Lycée une trace authentique et unique en Grèce d'un cannibalisme rituel perpétré au cours du banquet qui suivait le sacrifice des Lykaia'. ${ }^{37}$ But to read the myth as offering evidence of actual cannibalism is to overlook, or attempt to actualise, what are, it

29 Hes. fr. 163 MW; also found in Ov. Met. 1.210-44; Hyg. Astron. 2.4; Serv. ad Verg. Ecl. 6.41 and Aen. 1.731, 4.24; Lactantius Placidus ad Stat. Theb. 11.128.

30 [Apollod.] 3.8.1: Mainalos, the oldest son instigates the act. Cf. schol. ad Lyc. Alex. 481; [Hecataeus] FHG I no. 375 (cf. Natalis Comes 9.9 and Tzetzes ad Lyc. Alex. 481).

31 Nic. Dam fr. 39 (Dindorf); Suda s.v. Lykaon; Hyg. Fab. 176 (a son). Lykaon wants to know: Hyg. Astron. 2.4.

32 Hes. fr. 163 MW (Zeus puts Arkas back together; also Hyg. Poet. astron. 2.4); schol. ad German. Arat. 39.

33 Lyc. Alex. 481; Nonnus Dion. 18.21; Clem. Alex. Protr. 2.36.5; schol. ad Lyc. Alex. 481. In [Apollod.] 3.8.2, Nyktimos is the only child to survive.

34 [Apollod.] 3.8.1; and [Hecataeus] FHG I no. 375; Nic. Dam. fr. 39 (Dindorf) an anonymous child. Undescribed: Paus. 8.2.3. Just human flesh: Hyg. Fab. 176; Lactantius Placidus ad Stat. Theb. 11.128; Myth. Vat. 1.17 (Bode).

35 Serv. ad Aen. 1.731; Ov. Met. 1.226-27.

36 Jost 1985: 262.

37 Jost 1985: 264. Buxton 2006: 68-69 expresses doubt about the sacrifice, but comes to no definite conclusion. He does note that myth makes 'explicit and absolute' what ritual leaves 'implicit and temporary', but this is in the context of arguing that in the ritual the 'wolf 'would be expelled rather than killed as in the original myth' (ibid.: 74). 
is argued here, symbolic themes. More importantly, these themes, if anything, emphasise the wrongness of such a ritual, and give no reason to continue with such an act. ${ }^{38}$

The story as presented in the myth is replete with the idea of punishment. This comes in a variety of configurations across the sources: different accounts describe the destruction of Lykaon's house, and/or his children; sometimes Lykaon is a wolf, sometimes his children. Lykaon's house is destroyed by a thunderbolt and he is turned into a wolf. ${ }^{39}$ Sometimes, the sons are blasted while Lykaon becomes a wolf. ${ }^{40}$ Sometimes, some sons are blasted while others become wolves. ${ }^{41}$ Sometimes, no wolf metamorphosis is mentioned: instead, both father and son(s) are blasted with thunderbolts ${ }^{42}$ - or just the father. ${ }^{43}$ In Ovid, famously, the whole event is followed by the flood that wipes out the whole human race except for Pyrrha and Deukalion; Apollodoros mentions that some say there was a flood, but appears to be uncertain. ${ }^{44}$ The same aspect seems to be the focus of the iconography of Zeus Lykaios, which comprises many images of Zeus, always holding a thunderbolt; literary references to him make the same connection. ${ }^{45}$ This recalls his role as a weather god, but also inevitably brings to mind the punishment-wielding god. Overall,

38 Jost (ibid.) argues that this may be one of the kinds of sacrifices that the Greeks dared not forego: and compares it to the Bouphonia, in which the slaughter of a bull would have been a virtually criminal act for rural farmers. However, this is to make a parallel between a valuable and replaceable possession and human life, which is scarcely equivalent.

39 Hes. fr. 163 MW; Ov. Met. 1.240-43; Hyg. Astron 2.4; Lactantius Placidus ad Stat. Theb. 11.128; schol. ad German. Arat. 89; Myth Vat. 2.60 (Bode).

40 Hyg. Fab. 176.

41 [Hecataeus] FHG I no. 375; and schol. ad Lyc. Alex. 481.

42 [Apollod.] 3.8.1; Nic. Dam fr. 39 (Dindorf) all those who murdered the child; Suda s.v.

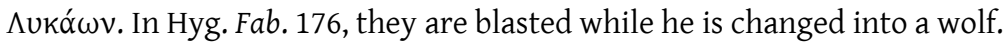

43 Serv. ad Verg. Ecl. 6.41.

44 Fowler 2013: 2.104 suggests this is evidence that the flood story occurred after Hesiod's tradition and before Apollodoros. Serv. ad Verg. Ecl. 6.41 also mentions a flood.

45 See discussion by Jost 1985: 252-54. Why Zeus receives the epithet Lykaios has long puzzled scholars, as Jost 1985: 250. 
the message of all these different versions of the story is that human sacrifice/cannibalism is wrong. ${ }^{46}$

The tale of Lykaon offers a reflection on what it is to be civilised. ${ }^{47}$ Buxton takes a symbolic interpretative approach to the story, and argues that the myth leads us to reflect on 'the importance of maintaining proper relationships with the gods'. Seeing an analogy with the myth of Prometheus, he reads the myth of Lykaon's activities as emphasising the rupture and gap between man and gods. ${ }^{48}$ The story as told by Pausanias marks cosmological change, and does so with a suitably shocking event: where once the gods sat at table with humans, now they no longer do so. The moment of Zeus' rage marks the moment when mortals transcend their earlier existence, when they lived in closer proximity to the divine, and come to inhabit the everyday world (of those telling the myth).

More specifically, alongside the theme of the justice of Zeus, this narrative raises questions about the nature of mortal political leadership,

46 The idea that the Arkadians themselves saw cannibalism as savage, and not a part of civilised human life, may underlie the text of the supposed Delphic response to the Phigaleians, when their failure to replace the statue of Black Demeter had produced a barren land (Paus. 8.42.7). The oracle threatens a gradual retreat from civilised diet - from cultivating cereals to herding to cannibalism (eating their children) - if the Phigaleians do not return to worship of Demeter. The reference to eating children recalls the myth of Lykaon (Bruit 1986: 80); it 'represents utter savagery' (Roy 2011: 75). Nielsen \& Roy 1999:34-36 have argued that the oracle was probably created after the cult was reinstated (the statue has been dated to roughly 470-460 BC); see Jost 1998: 264; cf. Roy 2011: 75.

47 And, in particular, what it was to be civilised in the landscape of Arkadia. Some versions of the narrative include aitia for places and natural features: e.g., the table that Zeus overturns in his rage provides the origin for the name of the city of Trapezous (Hes. fr. $163 \mathrm{MW}$; [Apollod.] 3.8.1). The child who is pieced together will later chase his mother into a forbidden sanctuary and Zeus will take them both up to become stars (Hes. fr $163 \mathrm{MW}$; Hyg. Poet. astron. 2.4). In the account of [Apollod.] 3.8.2, Kallisto is turned into a bear by Zeus after he has seduced her, to hide her from Hera; when this does not work (and Hera persuades Artemis to shoot her), he saves the baby, Arkas, and sets Kallisto in the stars as the Bear.

48 Buxton 2006: 73. Detienne 2003: 119 sees the rupture arising from the naming of Zeus as Lykaios. Compare with Anderson 2000: 92-97, who finds in this story traces of the fairytale type Red Riding Hood (AT Type 333) - thus, a story about 'butchering girls'. 
and the treatment of other human beings in one's community: it emphasises how a leader must face the consequences of his choices. The image of a wolf is perhaps particularly important here: in a number of ancient sources, the wolf is known not only as a savage killer, but also as a 'spontaneously "political" animal' who shares out its kill equally amongst the members of the community. ${ }^{49}$ In the context of this narrative, the use of this specific animal metamorphosis as punishment has particular resonance: has not Lykaon shared out the sacrifice appropriately? There is, in this analogy, a commentary on what it means to be human, rather than animal; what it is to perform a sacrifice rather than just share a kill. $^{50}$

Such an expansion of the interpretation of the significance and associations of Plato's analogy clarifies his use of it in the context of the irredeemable character of the tyrant, bringing to light the myth's themes of civilisation, leadership and responsibility. However, although it offers a rich set of references, the question of why Plato may have selected this particular myth to use here remains to be explored. The brief reference to it in the dialogue indicates that the author expected his audience to make appropriate associations relatively quickly. The suggestion of this article is that Plato employs this story not only to comment on the nature of tyranny, but also to direct the audience's attention to a particular aspect of the contemporary context, perhaps even a specific individual.

\section{ARKADIA: THEBES, SPARTA, ATHENS}

The argument has been made elsewhere that when Plato evoked the tyrant in the Republic, he had in mind Dionysios. ${ }^{51}$ However, while it may be observed that Plato visited Sicily in the early 380s, and that Dionysios

49 Detienne 2003: 120; and see Detienne \& Svenbro 1979: 216 for discussion of ancient sources.

50 Detienne 2003: 121 seems to see the problem of the wolf as located in or creating a confusion between killing and eating: "the murderer and its "knife" must not approach the dining table'.

51 Lewis 1994: 154-55. 
may be considered as 'the tyrant of the age', there is no compelling reason why Plato might use the image of an Arkadian ritual to refer to him. ${ }^{52}$ The wolf image not only illustrates the inhumanity of tyranny, it also brings to mind a particular region of the Peloponnese, raising the questions of Plato's motivation in introducing this focus, and, in turn, the nature of the contemporary association it would have suggested for those listening to this text. Scholarship has dated the composition of the $R e-$ public between 380-360 BC. This article suggests that Plato's use of this particular analogy, drawing on a well-known story from Arkadia, was intended to prompt reflection on the political situation after $371 \mathrm{BC}$, specifically, the political and military entanglements between Arkadia, Thebes, Sparta and Athens during the 360s, and to draw attention to the activities of a particular political leader, recently risen to power. ${ }^{53}$

After the Battle of Leuktra, Athens had allied with the Thebans, while a movement in support of an Arkadian federation emerged. This federation turned to Athens to ask for support; when Athens refused, it turned to Thebes. ${ }^{54}$ The Spartans, facing the invading force of Thebes also asked Athens for help, and the Athenians voted to support them, too. ${ }^{55}$ Their ostensible justification was that this was in accordance with the obligations of their oath at the Athenian conference of $371 \mathrm{BC} ;{ }^{.6}$ but Xenophon suggests that it was motivated by fear and loathing of Theban power and

52 For quotation see Lewis 1994: 155. It is possible that Plato had in mind the myth of Syrakuse's co-foundation from Arkadia (as well as Corinth), for which see Pind. Ol. 6.4-6 (the Iamidai) with Hornblower 2004: 184-86, but this would be an indirect, rather weak association.

53 Halliwell 1988: 1: 'probably composed over a number of years in the course of the 380s and, perhaps, early 370s BC'; Pappas 1988: 1: between 380 and 360. See Nails 1998: 385 on dramatic date and date of composition (she argues that there are good and bad reasons for the two most debated dramatic dates 421 and $411 \mathrm{BC}$, suggesting that the dialogue was 'cobbled together and revised over decades'). The dialogue is, as Annas 1991: 4 has put it, 'overtly transitional' between the earlier Sokratic dialogues in which Plato drew on Sokrates' own method, and the later dialogues in which Plato put forward his own views, albeit using Sokrates as his mouthpiece.

54 Diod. Sic. 15.62.3-64.4; Xen. Hell. 6.5.19.

55 Sparta faces Thebes plus forces from Phokis, Euboia, East and West Lokris, Akarnania, Herakleia, and Malis, along with cavalry and light-armed troops from Thessaly and forces from Arkadia, Argos and Elis.

56 Xen. Hell. 6.5.33-49; Dem. 16.12. 
its use. ${ }^{57}$ The Athenians sent Iphikrates into Arkadia through Corinth, but, by the time he got there, the Arkadians, Argives and Eleans had withdrawn, as had the Thebans with their allies.

To support Sparta in this way was a major change of Athenian policy, and we might expect that there would be some politicians in favour, while others were not. In this context, it could be argued that Plato's reflection on the wolf that has tasted human flesh might be taken most fittingly as a warning to the Athenians about the dangers of their renewed relationship with Sparta. Certainly, there were those at the time who asked questions about this choice of alliance. ${ }^{58}$ But biographical details about Plato suggest that he supported this alliance. In particular, he was connected to those in support of it, through one Kallistratos, who was widely understood to be responsible for the policy. ${ }^{59}$

57 Xen. Hell. 6.3.1. Webster 1970: 31 suggests that something of the negative feelings towards Thebes during this period may be gathered from the following fragment: 'Dishonesty in Oropos, Jealousy in Tanagra, Violence in Thebes, Greed in Anthedon, Officiousness in Koroneia, Boastfulness in Plataia, Fever in Onchestos, Stupidity in Haliartos' (Kock CAF iii: 469, no. 337). Webster accepts Kock's suggestion that this is a fragment of comedy, and states that the reference to Plataia indicates a date between $382 \mathrm{BC}$ (the city's restoration) and $373 \mathrm{BC}$ (its destruction). But the source is Heraclides Criticus De urb. Graec. 1.25, now dated to the early Hellenistic period (Pfister 1951) and so this cannot stand.

58 Including members of the Second Confederacy, Mytilene, in 369/8 (RO 31), for example; see Sealey 1993: 71.

59 Xen. Hell. 6.3.3; Kallistratos proposed the response to the Mytileneans, see Xen. Hell. 6.3.10; see also Arist. Rh.1411a5, and [Dem.] 59.27. Kallistratos was supported by Chabrias, who took part in a second campaign in the Peloponnese against an invading Theban force in 369. A late source reports that when, after $366 \mathrm{BC}$, Chabrias was put on trial for his role in losing the town of Oropos to the Thebans, only Plato would plead for him (Diog. Laert. 3.23-24). Kallistratos was also implicated in these events (he had suggested that the Thebans retain possession of Oropos; they then would not leave), see Arist. Rh. 1364a. Davies 1971: 462, 560-61 suggests a relationship by marriage between Chabrias and Eryximachos of Phaedrus 268a (cf. Symp. 175a-177d, 185d189c); but see Nails 2002: 143-44. Other possible links: Of the envoys sent to Sparta in 371, Xenophon (Hell. 6.3.2) provides a list, which includes Melanopos (PAA xii, 638765), ostensibly a rival of Kallistratos, but accused of being 'bought' by him (see Arist. Rh. 1374b). Melanopos was likely to have been a son of Laches; see Pl. Laches esp. 200c; Plut. Dem. 13; and Anaxandrides fr. 41 KA (= Ath. 553e), with Sansone 1996. Finally, there is also a story of Demosthenes deserting Plato in order to listen to and 
If not Sparta, then perhaps Thebes provides a better fit for the analogy: there are particular parallels between Theban activities and the tyrant's change from protector to aggressor. To begin with, it is likely that the wolf-man analogy reminded its audience of the foundation of Megalopolis, which had famously adopted the cult of Zeus Lykaios as one of its 'doublets'. The foundation involved the absorption of surrounding settlements: how this occurred is debated, but there is evidence of rebellions against the process and this may have been a situation in which a former protector was perceived as an aggressor. ${ }^{60}$ Some traditions stated that the foundation occurred with the help and guidance of the Theban general Epaminondas, and at least the support or protection of Theban troops. Evidence suggests that this was unlikely, but it could still be argued that the wolf-tyrant analogy was meant to bring to mind the Thebans, especially their behaviour towards their Arkadian allies, as that alliance fell apart in the mid-360s. ${ }^{61}$ There is evidence for the widespread perception that Thebes' behaviour towards its own allies was seen as tyrannical: e.g., the Theban destruction of Plataia in $373 \mathrm{BC}$, about which the Athenians had strong feelings. ${ }^{62}$ Reinforcing the case for Thebes is

follow Kallistratos (Hermippos ap. Aul. Gell. 3.13): An unlikely tale in itself, it could perhaps be taken as suggesting the opposition of these two figures, but may rather illustrate the difference perceived between philosophy and oratory, as well as providing a commentary on Demosthenes' character.

60 Diod. Sic. 15.94.1-3 describes a rebellion in $361 \mathrm{BC}$, but Pausanias' description of cities unwilling to join the new community (8.27.5) appears to be about an earlier event. See discussion of the synoikism and related scholarship in Nielsen 2002: 414-69; and 2015.

61 Diod. Sic. 15.72.4, 15.94.1-3; Paus. 8.27.1-8. See discussions by Nielsen 2002: 420; Hornblower 1990: 77; and Demand 1990: 117-18. Roy 2014 provides a succinct and compelling overview of the debate. Plato may even have had a longer perspective, and intended Thebes to remain the focus of his criticism. After Lykomedes' death, the situation worsened between Arkadia and Thebes: in $363 \mathrm{BC}$, a row over the use of temple funds (Olympia) caused a split between the Mantineans, who supported Sparta, and Tegeans, who remained loyal to Thebes. It would lead to a battle in which Epaminondas was killed. However, the Thebans continued to support Tegea, and to maintain the city of Megalopolis by constraining those who wanted to return home (361 $\mathrm{BC})$.

62 Xen. Hell. 6.3.1, 6.3.5: Isokrates in his Plataikos (14.8) offers a Plataian appeal to the Athenian assembly in the light of their city's annihilation: it makes it clear that 
evidence that the image of the wolf for Thebans in a military context may already have been active in political discourse. Pausanias relates a story that associates Epaminondas and the Thebans with the imagery of the wolf before the battle of Leuktra. ${ }^{63}$

Some aspects of the Theban parallel seem cogent, but questions remain in light of the fact that Plato's analogy focuses the reader's attention so completely on Arkadia. In conclusion, therefore, I want to introduce a final potential target for this analogy: the Arkadian politician, Lykomedes. As mentioned, the Theban-Arkadian alliance fell apart in 366; the result had immediate implications for Athens, when the Arkadians sought an alliance with their city. ${ }^{64}$ The Arkadian politician who helped to set up both alliances, was one Lykomedes, or 'wolf-sly', a name that encompassed not only the aggression of the wolf, but also its intelligence and enterprise. ${ }^{65}$ Xenophon, albeit briefly, seems to describe a character whose rise to power - and violent death - is mesmerizingly similar to that of his tyrant. ${ }^{66}$ Lykomedes was the dominant political figure in the Arkadian League following the battle of Leuktra until his death

Thebes had originally cast itself as the protector. This may have been prompted by fear that the Thebans might also attack them: in Xenophon's account, the Spartans are made to raise this when, in their request for an alliance, they remind the Athenians that the Thebans had asked for Athens to be destroyed after the Peloponnesian War (Xen. Hell. 6.5.35 and 46). Steinbock 2013: 330 observes how this speech, which does not mention Corinth or other poleis that had argued for the same approach to Athens, is characteristic of later Athenian attitudes to Thebes: 'The renewed hostility between Athens and Thebes between 371 and 340 sufficed to attach the memory of this proposal solely to the Thebans.'

63 Paus. 9.13.4, trans. W.H.S. Jones (adapted): he reports that 'Here heaven sent signs to the Lakedaemonian people and to Kleombrotos personally. The Lakedaemonian kings were accompanied on their expeditions by sheep, to serve as sacrifices to the gods and to give fair omens before battles. The flocks were led on the march by shegoats, called katoiades by the herdsmen. On this occasion, then, the wolves dashed on the flock, did no harm at all to the sheep, but killed the goats called katoiades.'

64 Athens remained allied to Sparta, Arkadia to Thebes: Xen. Hell. 7.1.39; 7.4.2.

65 See Xen. Hell. 7.1.23, where he gives an emotional speech concerning the strength of the Arkadians (including their autochthony) and urges them to be independent. On Lykomedes see now Nielsen 2015: 258-59, and nn. 41 and 42; on these attributes of the wolf, see Detienne \& Svenbro 1979: 217-18.

66 Xen. Hell. 7.1.24. 
- at the hands of exiled Arkadians - on the journey home from his negotiations with Athens. Could Plato's wolf-man analogy have been intended as a brief reflection on the character of this politician?

In terms of the analogical style of the allusion, the employment of such a poetic image to evoke the telling detail of a particular person's character is not unusual in the dialogues: when portraying both named and unnamed individuals, Plato employs poetic similes to emphasise aspects of their personalities. In doing so, he sometimes introduces allusive material that would have been familiar to his audience, ${ }^{67}$ and a number of these and other similes involve reference to ritual and mythological events or characters. ${ }^{68}$ Nor is the allusion to a contemporary figure or set of events so startling. A number of the dialogues, while set in a past era, are clearly intended to provide a critique of contemporary politics and society, and it seems unlikely that there were not subtle allusions to particular individuals and events, as well as the overt appearances by figures from Athens' historical and contemporary political scene; indeed, there have been a number of scholarly debates about some possible representations. ${ }^{69}$ More specifically in support of the argument that the werewolf

67 For the information on similes in Plato's works, I am indebted to Ziolkowski 2014, which provides ample examples. Examples of allusive material: the Heraklean [stone] referred to at Ion 1; an 'ancestral Zeus' (Euthyd. 16); sacred cattle (Prot. 2); those 'fabled to have ascended from Hades to the gods' (Resp. 7.9). Korybantes hear the auloi (Cri. 3); Eurykles speaking from within a man (Soph. 9). See further Ziolkowski 2014: App. II, D. http://wp.chs.harvard.edu/ziolkowski/appendix-ii/

68 A well-known example is Pl. Symp. 221c-d, where Brasidas is compared to Achilles and Perikles to Nestor or Antenor; Sokrates compares Dionysodoros to Medea of Kolchis (Euthyd. 7); comparison to Proteus (Ion 5); comparison to the Krommyonian sow (La. 2); to Typhon (Phdr. 1). See further Ziolkowski 2014: App. II, C. http://wp.chs.harvard.edu/ziolkowski/appendix-ii/.

69 The contemporary characters found in Plato's dialogues are listed in Nails 2002 and explored in Field 1948. My argument here does not disagree with Field 1948: 190, who argues that 'The idea that any character in the dialogues represents in details a contemporary person, so that we can ascribe every statement and argument put into his mouth to the living person whom he represents, is entirely unacceptable ... He represents only a current point of view.' Indeed, I agree with his description of Plato's approach as formulating the details of presentation of that individual (in this case, the espousal of a particular theory) so as to bring out its 'essential features... as clearly as possible for the purpose of examining its truth', and 'naturally, also, select 
analogy may refer to Lykomedes is some further evidence that Plato took a particular interest in the political situation in Arkadia, including the (much-debated) mention by Aristophanes in the Symposium of Arkadia, 'dispersed by the Spartans', which may refer to a dioikismos of Mantineia in either 418 or $385 \mathrm{BC} .{ }^{70}$ Two later sources also report that Plato was invited to come and act as nomothetes or lawgiver by the Arkadians and Thebans (sic) when they were founding Megalopolis, but he refused because the Arkadians did not want 'to have equality'. This story, although lacking detail, also suggests a Platonic concern with the nature of Arkadian political leadership. ${ }^{71}$

as its mouthpiece, whenever possible, some one who actually had affiliations with the view in question.' Field is here criticising the argument that the character of Kratylos in the dialogue of that name was meant to represent, in precise detail, the philosopher Antisthenes and his views. In contrast, Field does feel able to speculate that the Gorgias was prompted by a particular set of circumstances in Athens, and that the reference to Perikles at 515e would have been understood by his contemporary audience as describing the activities of Agyrrhios; Field 1948: 125. The reference to the tyrant Archelaos of Macedon in that same dialogue is explicit.

70 Pl. Symp. 193a: this is thought to show that Plato had a long-standing interest in the area, its unification or otherwise, but the exact event to which Aristophanes is referring is debated. Aelius Aristides (Or. 46.287 [Dindorf]) argued that this was the dioikismos of Mantineia in 385 BC. Wilamowitz 1919: 177-78 dated the Symposium to 381378 and argued that although the passage was prompted by the dioikismos, the setting of the dialogue was $416 \mathrm{BC}$, so the audience was meant to think of events in 418; Mattingly 1958: 31-39 argued that it refers to events in $418 \mathrm{BC}$, and for redating the dialogue. Finally, Dover 1965 argued that it referred only to events in 385/4.

71 Diog. Laert. 3.23 and Ael. VH 2.42; see Roy 2000: 311, who observes that the Arkadians may have understood isonomia differently from Plato, and so this does not mean that the city was not democratic, but that it may have had particular guidelines; see also Trampedach 1994: 37-41; and Nielsen 2015: 261 n. 57 on the historicity of this account. According to other sources, Plato sent one Aristonymos, an associate, to organise or reorganise the constitution (Plut. Mor. 1126c = Adv. Colotem 32); see Trampedach 1994: 91. 


\section{CONCLUSION}

In making this final suggestion, this article is not attempting to identify the precise circumstances or events to which the werewolf analogy refers. The difficulties of eliciting the historical reality of a cult from an associated myth are well known; the problems of identifying a political situation or figure may be regarded as, at least, equivalent. ${ }^{72}$ Rather, it intends to indicate the possibilities for interpretation that are created by attempting to set Plato's brief mention of this myth in a historical context. Ultimately, what we can say about the ritual to which Plato alludes is extremely limited. ${ }^{73}$ For the Arkadians, 'becoming a wolf may have been some kind of priesthood, or an initiation ritual limited to one ageclass, or eventually one family. ${ }^{74}$ In that ritual, recalling the punishment of Lykaon, an individual seems to have become 'a wolf', a position he then held for some nine years; in the tenth, the ritual was re-enacted, and the role passed to someone else. It may have been some form of initiation for some or all of Arkadian youth, but that is far from obvious. ${ }^{75}$ The ritual may or may not also have included swimming across a body of water; but,

72 See Brillante 1990 for thoughtful exploration of this topic.

73 That change occurs in the tenth year has an element of traditional story structure to it, e.g. in the Odyssey there is a repeated pattern of nine days passing before events change on the tenth day.

74 It has been suggested, on this basis of the argument for initiation, that Pausanias was making a link between Arkadian warriors and wolves when he mentions that the Arkadian warriors, fighting for Aristodemos against the Spartans, wore the skins of the wolf and the bear (4.11.3); Buxton 1987: 71; cf. Burkert 1983: 91. But Pausanias is describing the lack of armour among the Arkadians and Messenians: he mentions specifically how some were protected with animal skins instead, such as those of goats and sheep, and, with reference to the Arkadian mountaineers, wolf and bear skins. This does suggest that those who lived in the mountains were hardier and less civilised - a common association with mountain-dwellers (Arr. An. 7.9.2; Paus. 10.17.8-9; see discussion in Buxton 2013: 9-32) - but it is not evidence for a ritual in which Arkadians, all or some, were initiates.

75 Buxton 1987: 72 is rightly concerned about the length of time of this initiation: 'we have to give a reasonable answer to the question, "What were they doing for nine years?"'; cf. Jost 1985: 267. 
on the basis of the myth, which suggests that the slaughter and consumption of a human was a wholly unacceptable practice, it seems unlikely that actual human sacrifice was involved. ${ }^{76}$

The wolf narrative is one of many stories or allusions to stories that Plato uses in the Republic. ${ }^{77}$ Indeed, the dialogue hinges on a much-discussed ambiguity: it criticises and condemns the mimetic arts, but does so in a form that is itself mimetic. ${ }^{78}$ As the dialogue progresses, the dangers of mimesis are enumerated, until Book 10, where Sokrates states that they were right to have banned mimetic poetry from the ideal state. ${ }^{79}$ But the structure of the argument is not straightforward: in the earlier parts of the discussion it has been stated that there is a place for good mimetic poetry. ${ }^{80}$ One of the important early arguments made in this context concerns the ways in which stories are a way of communicating information to children, a process that occurs at the earliest and most crucial stage of their learning. ${ }^{81}$ Plato explains that myths that cast the gods in a bad light are dangerous, they teach the wrong values and can be used to justify immoral mortal behaviour. ${ }^{82}$

76 The debate on this aspect of sacrifice in Greek culture continues. Hughes 2013 and Bonnechere 2009 [1994] have argued against it, but other scholars examine the evidence with less firm conclusions: e.g. Henrichs 1974: 232-33; Bremmer 2007: 79, esp. 78 on Lykaon.

77 See Morgan 2000: 162 on three loose classes of myths employed by Plato in his dialogues.

78 The dialogue is itself a play, set sometime between 431 and 411; see Rosen 2005: 20 and Nails 1998 (n. 48 above) and the characters themselves refer to their activities

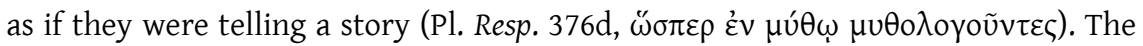
dialogue itself ends with a famous 'myth of judgment'; see Taylor 1926: 265.

79 Pl. Resp. 376e-400b, 400c-3c; $595 \mathrm{a} 5$.

80 Pl. Resp. 400d11-2a6; see Murray 1996: 4-6.

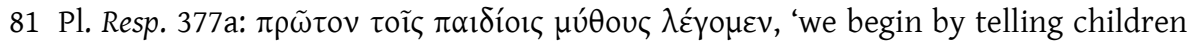
stories.'

82 Pl. Resp. 378a1-2 on the myth of Kronos, and see Pl. Euthyphr., where Euthyphro uses this myth to justify his prosecution of his own father. See Murray 1996: 139 (ad 378a1-2); she notes Burnet's (1924 ad loc.) observation that this argument was used in fifth-century debates about nomos and physis. Towards the end of the dialogue, two arguments are being made to justify the banning of mimetic poetry: first that it corrupts, since it imitates the wrong kinds of behavior (605c10-8b2); and, second, 
Is it fundamentally contradictory for Plato to use a story, like that of the Arkadian werewolf, when he has himself condemned the use of the mimetic arts? An answer may lie in the terms he uses to describe this tale. This story of the werewolf is referred to as both mythos and logos: that is, it is a traditional tale that also seems to offer something more rational, more carefully directed..$^{83}$ Indeed, the allusion to the myth of Lykaon aligns well with Plato's professed role for myths in his ideal city, insofar as it is a story of mortal crime and divine punishment. And, as he must have recognised, the myth of the werewolf is very powerful. 'This crisis of the coincidence of the natural and the human' as Susan Wiseman has described the appearance of the werewolf (with reference to the sixteenth-century wolf-man Peeter Stubbe, the 'Werewolf of Bedburg'), is long-lived, cross-cultural, and rich with possible insights. ${ }^{84}$

I have argued that Plato used this analogy for two reasons: first, he was concerned with the general lessons to be learned from a myth that illustrated the power and responsibilities of leadership, apposite for his reflection on the role of the tyrant. And beyond that, I would argue, the werewolf of Plato's analogy was intended as a reflection on one Arkadian politician in particular. Thus, when it is considered as a historical text, this analogy can offer scholars a prism for viewing a society and its cultural imaginary: hold it one way and it reveals a legacy of folklore; another facet offers insights into the relationship between man, animal and

because poets do not know what goodness is, so cannot represent it in their art (598d 7-99e6).

83 The question of the relationship between mythos and logos is much discussed: a seminal collection of articles is Buxton 1990. For Plato's treatment here see Morgan 2000: 283-86, esp. 286; Murray 1999. Burkert 1983: 88 notes only the use of mythos and takes it as indicating Platonic scepticism. Albinus 1998: 92 observes that importantly this is a mythos that is part of logos, so is a story added to 'a frame of didactic or dialogical speech', different from the free-standing traditional mythoi that Plato criticizes and aims to control. He analyses the exception, the myth of Er, as itself used (100; italics in original) 'as a traditional frame within which philosophy was the real thing to choose.'

84 Quotation: Wiseman 2004: 55. The bibliography on werewolves is vast, and so I have included only what I have found especially useful, including Wiseman 2004; Gordon 2015 (as one of a number of enthralling articles in Blécourt 2015). 
the gods; a further facet may allow a glimpse of contemporary political concerns.

\section{BIBLIOGRAPHY}

Albinus, L. 1998. ‘The Katabasis of Er. Plato's Use of Myths, Exemplified by the Myth of Er' in E.N. Ostenfeld (ed.) Essays on Plato's Republic. Aarhus, 91-105.

Anderson, G. 2000. Fairytale in the Ancient World. London.

Annas, J. 1991 [1981]. An Introduction to Plato's Republic. Oxford.

Blécourt, W. de. 2015. Werewolf Histories. Basingstoke.

Bode, G.H. 1834. Scriptores rerum mythicarum latini tres Romae nuper reperti. 2 vols. Cellis.

Bonnechere, P. 1994. Le sacrifice humain en Grèce ancienne. Liége [http://books.openedition.org/pulg/1038 (accessed 09/11/16)].

Bonnechere, P. 2009. 'Le sacrifice humain grec entre norme et anormalité' in P. Brulé (ed.) La norme en matière religieuse en Grèce ancienne: Actes du XIIe colloque international du CIERGA (Rennes, septembre 2007). Liége, 189-212.

Bouvier, D. 2015. 'Le héros comme un loup: usage platonicien d'une comparaison homérique' Cahiers des études anciennes 51, 125-47.

Bremmer, J. 2007. 'Myth and Ritual in Greek Human Sacrifice: Lykaon, Polyxena and the Case of the Rhodian Criminal' in J. Bremmer (ed.) The Strange World of Human Sacrifice. Leuven, Paris \& Dudley, MA, 5580.

Brillante, C. 1990. 'Myth and History: History and the Historical Interpretation of Myth' in L. Edmunds (ed.) Approaches to Greek Myth. Baltimore, MD, 91-140.

Brock, R. 2013. Greek Political Imagery from Homer to Aristotle. London.

Brown, E. 2011. 'Plato's Ethics and Politics in The Republic' in E.N. Zalta

(ed.) The Stanford Encyclopedia of Philosophy [http://plato.stanford.edu/ archives/win2011/entries/plato-ethics-politics (accessed 09/11/16)]. Bruit, L. 1986. 'Pausanias à Phigalie. Sacrifices non-sanglants et discours idéologique' Metis 1, 71-96. 
Burkert, W. 1983. Homo Necans: The Anthropology of Ancient Greek Sacrificial Ritual and Myth. Berkeley \& Los Angeles, 84-93 [orig.: Berlin 1972].

Burnet, J. 1924. Plato, Euthyphro, Apology of Socrates and Crito. Oxford.

Buxton, R.G.A. 1987. 'Wolves and Werewolves in Greek Thought' in J. Bremmer (ed.) Interpretations of Greek Mythology. London, 60-79 [rev. version in Buxton 2013: 33-51].

Buxton, R.G.A. (ed.) 1990. From Myth to Reason? Studies in the Development of Greek Thought. Oxford.

Buxton, R.G.A. 2013. Myths and Tragedies in their Ancient Greek Contexts. Oxford.

Canto, M. 1986. 'Entre chien et loup: le philosophe et le sophiste' in B.B. Cassin (ed.) Positions de la sophistique. Paris, 27-51.

Demand, N. 1990. Urban Relocation in Archaic and Classical Greece: Flight and Consolidation. London.

Detienne, M. 2003. 'At Lycaon's Table' in M. Detienne (ed.) The Writing of Orpheus. Baltimore, 115-22.

Detienne, M. \& J. Svenbro 1979. 'Les Loups au festin ou la Cité impossible' in M. Detienne \& J.-P. Vernant (eds.) La Cuisine du sacrifice en pays grec. Paris, 215-37.

Dover, K. 1965. 'The Date of Plato's Symposium' Phronesis 10.1, 2-20.

Field, G.C. 1930. Plato and his Contemporaries: A Study in Fourth-century Life and Thought. London.

Gordon, R. 2015. 'Good to Think: Wolves and Wolf-men in the GraecoRoman World' in W. de Blécourt (ed.) Werewolf Histories. Basingstoke, 25-60.

Halliwell, S. 1988. Plato: Republic 10. Warminster.

Henrichs, A. 1974. 'Human Sacrifice in Greek Religion: Three Case Studies' in J. Rudhardt \& O. Reverdin (eds.) Le Sacrifice dans l'Antiquité (Entretiens sur l'Antiquité Classique 27). Genève, 195-235.

Hornblower, S. 1990. 'When was Megalopolis Founded?' BSA 85, 70-77.

Hornblower, S. 2004. Thucydides and Pindar: Historical Narrative and the World of Epinikian Poetry. Oxford.

Hughes, D. 2013. Human Sacrifice in Ancient Greece. London.

Hyde, W. 1903. De olympionicarum statuis a Pausania commemoratis. Halis Saxonum. 
Jeanmaire, H. 1939. Couroi et Courètes: essai sur l'éducation spartiate et sur les rites d'adolescence dans l'antiquité hellénique. Lille.

Jost, M. 1985. Sanctuaires et cultes d'Arcadie. Paris.

Jost, M. 1992. 'Sanctuaires ruraux et sanctuaires urbains en Arcadie' in A. Schachter (ed.) Le sanctuaire grec (Entretiens sur l'Antiquité Classique 37). Genève, 205-38.

Jost, M. 1994. 'The Distribution of Sanctuaries in Civic Space in Arkadia' in S.E. Alcock \& R. Osborne (eds.) Placing the Gods. Oxford, 217-30.

Jost, M. 1996. 'Les cults dans une ville nouvelle d'Arcadie au IVème siècle: Megalopolis' in P. Carlier (ed.) Le IVe siècle av. J.-C.: approches historiographiques (Collection Études Anciennes 15). Paris, 103-9.

Jost, M. 1998. 'Commentaire' in M. Casevitz, M. Jost \& J. Marcadé (eds.)

Pausanias: Description de la Grèce, Livre VIII: L'Arcadie. Paris, 161-293.

Jost, M. 2002. 'À propos des sacrifices humains dans le sanctuaire de Zeus du mont Lycée’ in R. Hägg (ed.) Peloponnesian Sanctuaries and Cults: Proceedings of the Ninth International Symposium at the Swedish Institute at Athens, 11-13 June 1994. Stockholm, 183-86.

Jowett, B. 1871. The Dialogues of Plato, translated into English with analyses and introductions. Vol. 3. Republic, Timaeus, Critias. Oxford.

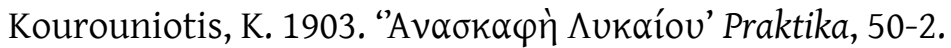

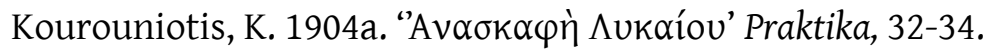

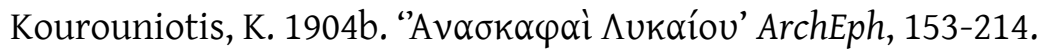

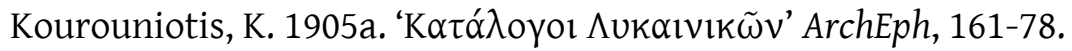

Kourouniotis, K. 1905b. Congrès d'Athènes, 255-56.

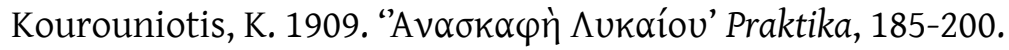

Kunstler, B. 1991. 'The Werewolf Figure and Its Adoption into the Greek Political Vocabulary' The Classical World 84.3, 189-205.

Lewis, D. 1994. 'Sicily, 413-368 BC' in D.M. Lewis, J. Boardman, S. Hornblower \& M. Ostwald (eds.) The Cambridge Ancient History. Vol 6. The Fourth Century BC. Cambridge, 120-55.

Mainoldi, C. 1984. L'image du loup et du chien dans la Grèce ancienne d'Homère à Platon. Paris.

Mattingly, H. 1958. 'The Date of Plato's Symposium' Phronesis 3.1, 31-39. Moretti, L. 1957. Olympionikai. Roma.

Morgan, K. 2000. Myth and Philosophy from the Pre-Socratics to Plato. Cambridge. 
Mt. Lykaion Excavation and Survey Project [http://lykaionexcavation.org]. Murray, P. 1996. Plato on Poetry. Ion; Republic 376e-39869; Republic 595-608b10. Cambridge.

Murray, P. 1999. 'What is a Muthos for Plato?' in R.G.A. Buxton (ed.) From Myth to Reason? Studies in the Development of Greek Thought. Oxford, 25162.

Nails, D. 1998. 'The Dramatic Date of Plato's Republic' CJ 93.4, 383-96.

Nails, D. 2002. The People of Plato: A Prosopography of Plato and Other Socratics. Indianapolis, IN.

Nielsen, T.H. 2002. Arkadia and its Poleis in the Archaic and Classical Periods (Hypomnemata 140). Göttingen.

Nielsen, T.H. 2015. 'The Arkadian Confederacy' in H. Beck \& P. Funke (eds.) Federalism in Greek Antiquity. Cambridge, 250-68.

Pappas, N. 1988. The Routledge Guidebook to Plato's Republic. London.

Pfister, F. 1951. Die Reisebilder des Herakleides: Einleitung, Text, Übersetzung und Kommentar mit einer Übersicht über die Geschichte der griechischen Volkskunde. Wien.

Pirenne-Delforge, V. 2008. Retour à la source. Pausanias et la religion grecque (Kernos Suppl. 20). Liège.

Romano, D.G. \& M.E. Voyatzis 2014. 'Mt. Lykaion Excavation and Survey Project, Part 1: The Upper Sanctuary' Hesperia 83.4, 569-652.

Romano, D.G. \& M.E. Voyatzis 2015. 'Mt. Lykaion Excavation and Survey Project, Part 2: The Lower Sanctuary' Hesperia 84.2, 207-76.

Rosen, S. 2005. Plato's Republic: A Study. New Haven \& London.

Roy, J. 1968. 'The Sons of Lycaon in Pausanias' Arcadian King-list' ABSA 63, 287-92.

Roy, J. 2000. 'Problems of Democracy in the Arcadian Confederacy 370362 BC' in R. Brock \& S. Hodkinson (eds.) Alternatives to Athens. Varieties of Political Organization and Community in Ancient Greece. Oxford, 308-26. Roy, J. 2011. 'On seeming backward: how the Arkadians did it' in S.D. Lambert (ed.) Sociable Man: Essays on Ancient Greek Social Behaviour in Honour of Nick Fisher. Swansea, 67-85.

Roy, J. 2014. 'Emplekton Technique in Fortification at Ithome/Messene, Megalopolis, and Mantinea: the work of Theban military engineers?' in R. Frederiksen (ed.) Proceedings of the Danish Institute at Athens. Aarhus, 123-31. 
Sansone, D. 1996 'Perfume from Peron's: The Politics of Pedicure in Anaxandrides Fragment 41 Kassel-Austin' ICS 21, 69-86.

Saxonhouse, A.W. 1978. 'Comedy in Callipolis: Animal Imagery in the Republic' American Political Science Review 72.3, 888-901.

Sealey, R. 1993. Demosthenes and His Time: A Study in Defeat. Oxford.

Shorey, P. 1969. Plato in Twelve Volumes. Vols. 5 \& 6. Cambridge, MA \& London.

Sinclair, T.A. 1948. 'Plato's Philosophic Dog' CR 62.2, 61-62.

Steinbock, B. 2013. Social Memory in Athenian Public Discourse: Uses and Meanings of the Past. Ann Arbor, MI.

Taylor, A.E. 1955 [1926]. Plato: The Man and His Work. 6th edition. London. Trampedach, K. 1994. Platon, die Akademie und die zeitgenössische Politik. Stuttgart.

Webster, T.B.L. 1970. Studies in Later Greek Comedy 400-370 BCE. Manchester. Wilamowitz-Moellendorf, U. von 1919. Platon, 2 vols. Berlin.

Wilamowitz-Moellendorf, U. von 1971. Kleine Schriften V.2: Glaube und Sage (besorgt von L. Malten). Berlin.

Wiseman, S. 2004. 'Hairy on the Inside: Metamorphosis and Civility in English Werewolf Texts' in E. Fudge (ed.) Renaissance Beasts: Of Animals, Humans, and Other Wonderful Creatures. Chicago, IL, 50-69.

Ziolkowksi, J. 2014. Plato's Similes: A Compendium of 500 Similes in 35 Dialogues. Cambridge, MA [http://wp.chs.harvard.edu/ziolkowski/ (accessed 09/11/16)].

Esther Eidinow

University of Bristol

esther.eidinow@bristol.ac.uk 